\title{
Climate change stimulates the growth of the intertidal macroalgae Ascophyllum nodosum near the northern distribution limit
}

\author{
Núria Marbà, Dorte Krause-Jensen, Birgit Olesen, \\ Peter B. Christensen, Anissa Merzouk, Joao Rodrigues, \\ Susse Wegeberg, Robert T. Wilce
}

\begin{abstract}
Ascophyllum nodosum is a foundation macroalgae of the intertidal zone that distributes across latitude $41.3-69.7^{\circ} \mathrm{N}$. We tested the hypothesis that growth of $A$. nodosum near the northern distribution edge increases with warming. We retrospectively quantified the growth of eight $A$. nodosum populations at West Greenland and North Norway (from $64^{\circ} \mathrm{N}$ to $69^{\circ} \mathrm{N}$ ). For seven populations, we measured growth rates since 1997-2002 and for one of them we extended the time series back to 1956 using published estimates. Individuals at northern populations elongated between 2.0 and $9.1 \mathrm{~cm} \mathrm{year}^{-1}$ and this variability correlated with temperature and annual icefree days. A spatial comparison of A. nodosum growth across the species distribution range showed that Northern (and coldest) populations grew at the slowest rates. Our results demonstrate that arctic climate change enhances the growth of $A$. nodosum populations and suggest that their productivity may increase in response to projected global warming.
\end{abstract}

Keywords Elongation - Greenland - Latitude gradient . Norway · Warming

\section{INTRODUCTION}

The arctic climate is rapidly changing due to excessive anthropogenic greenhouse gas emissions to the atmosphere (IPCC 2014). The Arctic Ocean ranks amongst the oceans warming at the fastest rate, twice as fast as the global ocean, and it experiences the largest thermal marine

Electronic supplementary material The online version of this article (doi:10.1007/s13280-016-0873-7) contains supplementary material, which is available to authorized users. seasonal shifts recorded globally since 1960 (Burrows et al. 2011). Arctic warming is also evidenced by the rapid loss of sea ice cover during the last decades, which reached the minimum extension ever recorded in 2012 (Vaughan et al. 2013). Arctic warming is expected to continue and, even under a mild scenario of greenhouse gas emissions (i.e., IPCC scenario RCP4.5), global models project a median of $4.9^{\circ} \mathrm{C}$ (maximum $9.3^{\circ} \mathrm{C}$ ) warming by the end of the twenty-first Century (Christensen et al. 2013).

Footprints of current arctic climate change are already evident in marine arctic ecosystems (Wassmann et al. 2011). Yet, climate change impacts on arctic macroalgal communities remain largely unexplored, despite knowledge about macroalgal responses to climate change being particularly relevant for forecasting the future functioning of coastal arctic ecosystems (Krause-Jensen and Duarte 2014). A major limiting factor is the sparsity of long-term datasets on arctic benthic vegetation, which are limited to scattered information from Svalbard fjords (Weslawski et al. 2010; Fredriksen and Kile 2012; Fredriksen et al. 2014; Kortsch et al. 2012; Bartsch et al. 2016), Greenland coasts (Krause-Jensen et al. 2012; Olesen et al. 2015) and Canadian coasts (Merzouk and Johnson 2011).

Macroalgae, mostly phaeophyta, are the dominant marine vegetation along the arctic and sub-arctic coasts, where they form lush and productive populations (Pedersen 2011; Krause-Jensen et al. 2012) and provide important ecological goods and services such as primary production, nutrient retention, habitat complexity, marine biodiversity, fertiliser and food production (Steneck et al. 2002; Schmidt et al. 2011). Macroalgal growth, survival and reproduction in northern regions are largely controlled by climatic conditions such as light, temperature and, for intertidal species, also icebergs and sea ice scour (e.g., Zacher et al. 2009; Wiencke and Amsler 2012). Climate conditions 
along the sub-arctic and arctic coasts reach extreme values and exhibit wide seasonal fluctuations partly due to the arctic dark season in combination with the development of sea ice that result into days to months of $24 \mathrm{~h}$ darkness above the Arctic Circle $\left(66^{\circ} \mathrm{N}\right)$. Ice scour from icebergs and pack ice particularly impacts intertidal rocky shores, and, thus, lush intertidal seaweed populations mostly develop in sheltered areas. Latitudinal variations in climatic conditions along the sub-arctic and arctic regions determine the position of biogeographical distribution edges of species (Müller et al. 2009) and may constrain macroalgal growth and productivity as observed in kelp forests (Krause-Jensen et al. 2012). Recent studies document poleward migration of geographical distribution ranges of marine biota, including macroalgae, in response to ocean warming (Poloczanska et al. 2013; Yesson et al. 2015; Straub et al. 2016). There is limited in situ documentation of responses of macroalgae along sub-arctic and arctic coasts. Instead, laboratory studies of temperature tolerance and response are used as a basis for predictions of future distribution limits and response to climate change (e.g., Müller et al. 2009; Wilson et al. 2015; Wilce 2016).

The brown macroalga Ascophyllum nodosum is a key foundation species, as it plays a strong role in structuring coastal communities (Schmidt et al. 2011), that occurs along sheltered intertidal rocky shores of North Atlantic coasts, from $41.3^{\circ} \mathrm{N}$ to $69.7^{\circ} \mathrm{N}$ (South and Titley 1986; Lüning 1990). Greenland, North Norway and South Baffin Island (Canada) host the northernmost $A$. nodosum populations described to date (Lüning 1990; Pedersen 2011). The broad geographical distribution of A. nodosum reflects its wide thermal tolerance, which ranges from less than $0{ }^{\circ} \mathrm{C}$ and up to about $25^{\circ} \mathrm{C}$ with optimal temperature at around $15^{\circ} \mathrm{C}$ (Fortes and Lüning 1980), considerably above current temperatures in the sub-arctic and arctic region. A. nodosum is a branched perennial species, with thalli that persist for 10-20 years (Stengel and Dring 1997) and the lifespan of individuals modelled at up to 300 years (Åberg 1992). Vegetative growth occurs primarily through elongation of the tips of the thallus while producing annually one bladder per tip (Macfarlane 1933). The growth form and architecture of $A$. nodosum thereby enable to retrospectively quantify growth of the thallus based on a single sampling event, and explore the possible drivers (e.g., climate change) of decadal variability in the growth records. Hence, the retrospective assessment of A. nodosum growth in relation to temperature changes can help assessing the possible impact of arctic climate change on its populations, even at remote sites such as the northern edge of the distribution range. This approach as has been done in the past for the arctic cockle Clinocardium ciliatum to test the effect of the length of sea ice season on annual growth (Sejr et al. 2009). While studies of A. nodosum response to climate change have been conducted at the southern edge of the geographical distribution (Araújo et al. 2014; Viana et al. 2014), no similar reports exist for the northern edge of its geographical distribution. The few projections of northern range expansion do not include the northernmost Greenland A. nodosum populations (Jueterbock et al. 2013; Neiva et al. 2016).

Here we assess whether arctic climate (i.e., temperature, sea ice cover) change affects growth of Ascophyllum nodosum populations at the northern fringe of the subarctic. We do so by retrospectively quantifying seaweed growth in six Greenlandic and two Norwegian populations between $64.2^{\circ} \mathrm{N}$ and $69.2^{\circ} \mathrm{N}$ since $1997-2002$ and examine its relation with climatic forcing. Moreover, we examine large-scale patterns in A. nodosum growth in relation to variability in summer seawater temperature across the entire biogeographical distribution range of the species. We discuss how projected arctic warming, under the IPCC scenarios of greenhouse gas emissions (IPCC 2014), may affect the productivity of $A$. nodosum at the northern distribution limit of the species during the twenty-first century.

\section{MATERIALS AND METHODS}

\section{Study sites}

Eight sites were studied along the coasts of West Greenland and North Norway (Fig. 1a). Greenland's west coast study sites extend from Kobbefjord (two sites) and Kapisillit in the Godthåbsfjord system, Nuuk, at $64^{\circ} \mathrm{N}$, Sisimiut at $67^{\circ} \mathrm{N}$ to Qeqertarsuaq and Kronprinsens Ejland on/by the Disko Island at $69^{\circ} \mathrm{N}$, which represent the northernmost observations of Ascophyllum nodosum in Greenland. We included two additional study sites in northern Norway, Hell on the Lofoten Islands $\left(68^{\circ} \mathrm{N}\right)$ and Troms $\varnothing\left(69^{\circ} \mathrm{N}\right)$, i.e., at similar latitude as the northernmost Greenland sites, but subjected to the warmer waters of the Gulf Current. Our A. nodosum collections were made between the years 2009 and 2012 at the mid-intertidal zone in August/September except those at Troms $\varnothing$ which we sampled in January (Table 1).

The dataset was further supplemented by historical observations of A. nodosum growth from the northernmost Greenland sites collected by R.T. Wilce at Kronprinsens Ejland in June 1959 and June 1986 and by Louise Hansen at Qeqertarsuaq in June 1999 (Hansen 2004). For the specimens collected in $1959(n=19)$ and $1986(n=20)$, growth was measured on herbarium specimens and corrected for the ca. 10\% shrinking due to drying (Hansen 2004). Annual growth estimates provided by Hansen (2004) were derived from measurements on 21 individuals 

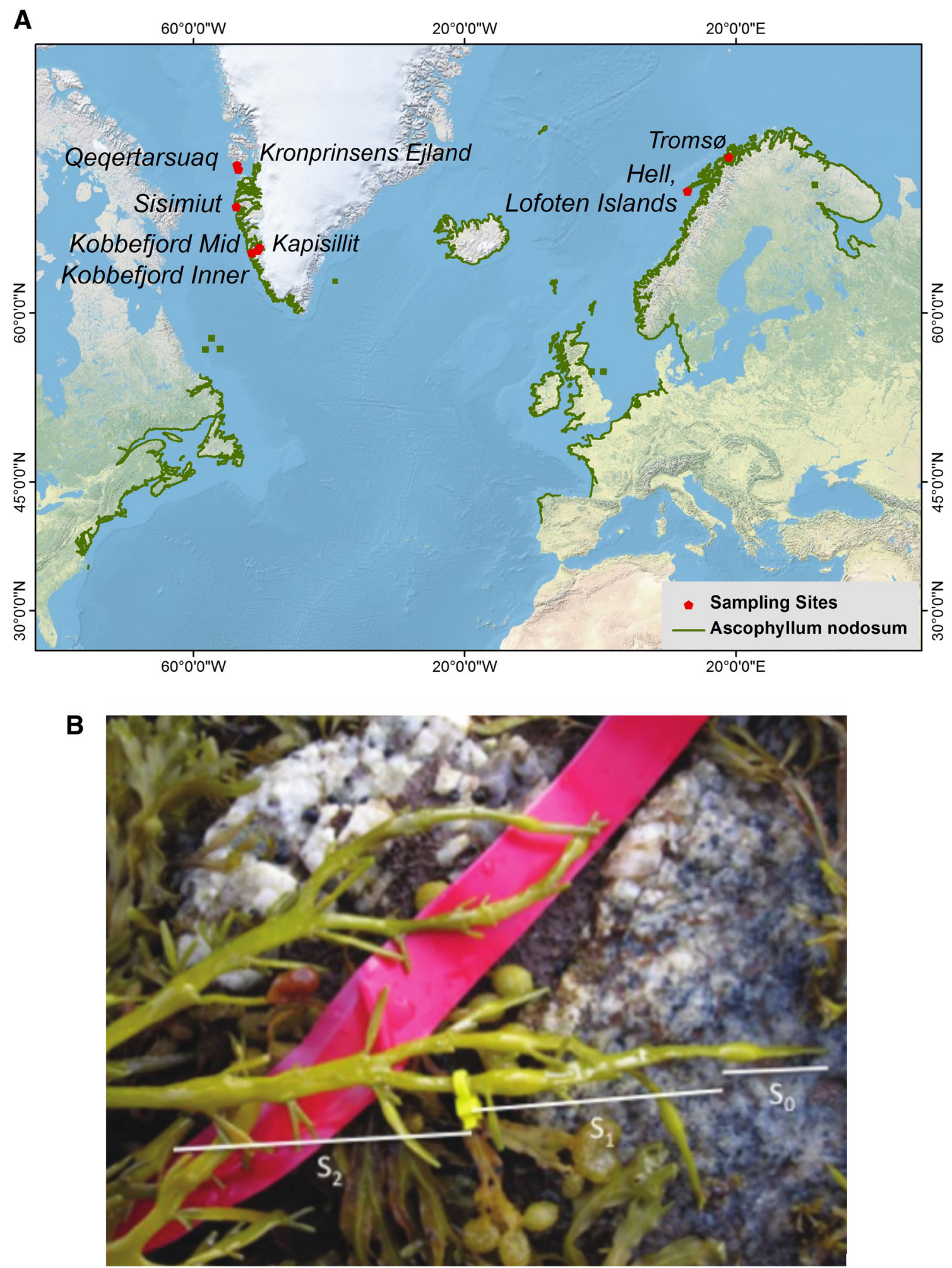

Fig. 1 a Location of study sites. b Ascophyllum nodosum tip showing the three youngest internodes: $S_{0}$ (produced the current year), $S_{1}$ (produced the previous year), $S_{2}$ (produced 2 years earlier). The yellow marking was used to test the assumption that a new bladder is produced every year: the production of a new bladder apparently displaced the yellow mark from its original the position between the youngest and the second youngest bladder to the position between the second and third youngest within 1 year 
Table 1 Name and coordinates of Ascophyllum nodosum sampling sites, name of the meteorological station nearby the sampling sites and name of the area surveyed for annual ice-free days. The dates of seaweed sampling and the starting and ending years of time series are provided. Historical information of growth was available from two sites

\begin{tabular}{lllll}
\hline Site & $\begin{array}{l}\text { Seaweed sampling date } \\
\text { (day/month/year); starting and } \\
\text { ending years of growth time } \\
\text { series }\end{array}$ & $\begin{array}{l}\text { Source annual } \\
\text { tip elongation }\end{array}$ & $\begin{array}{l}\text { Source ice-free days } \\
\text { (site); starting and ending } \\
\text { years of time series }\end{array}$ & $\begin{array}{l}\text { Source air temperature } \\
\text { (meteorological station); } \\
\text { starting and ending years of } \\
\text { time series }\end{array}$ \\
\hline
\end{tabular}

\begin{tabular}{|c|c|c|c|c|}
\hline \multicolumn{5}{|l|}{ West Greenland } \\
\hline \multicolumn{5}{|l|}{ Godthåbsfjord system } \\
\hline \multirow[t]{2}{*}{ Kobbefjord Inner } & $15 / 8 / 2010$ & 1 & 3 (Nuuk) & 4 (Nuuk-04250) \\
\hline & 1997-2009 & & 1990-2009 & 1958-2012 \\
\hline \multirow[t]{2}{*}{ Kobbefjord Mid } & $13 / 8 / 2010$ & 1 & 3 (Nuuk) & 4 (Nuuk-04250) \\
\hline & 1997-2009 & & 1990-2009 & 1958-2012 \\
\hline \multirow[t]{2}{*}{ Kapisillit } & $5 / 8 / 2011$ & 1 & - & 4 (Nuuk-04250) \\
\hline & 2010 & & & 1958-2012 \\
\hline \multirow[t]{3}{*}{ Sisimiut } & $28 / 8 / 2009$ & 1 & 3 (Sisimiut) & 4 (Sisimiut-04230 \\
\hline & 2000-2008 & & 1990-2009 & Sisimiut-04234) \\
\hline & & & & 1961-2012 \\
\hline \multicolumn{5}{|l|}{ Disko Bay } \\
\hline \multirow[t]{2}{*}{ Qeqertarsuaq } & 29/8/2009, 1999 & 1,2 & 3 (Qeqertarsuaq) & 4 (Aasiaat-04220) \\
\hline & 1997-2008 & & 1990-2009 & 1958-2011 \\
\hline \multirow[t]{2}{*}{ Kronprinsens Ejland } & 19/8/2012, 1959, 1986 & 1,2 & 3 (Qeqertarsuaq) & 4 (Aasiaat-04220) \\
\hline & 1957-2011 & & 1990-2009 & 1958-2011 \\
\hline \multicolumn{5}{|l|}{ Norway } \\
\hline \multirow[t]{2}{*}{ Hell, Lofoten } & $16 / 7 / 2010$ & 1 & - & 5 \\
\hline & 1997-2009 & & & 1900-2015 \\
\hline \multirow[t]{2}{*}{ Troms $\emptyset$} & $26 / 1 / 2011$ & 1 & - & 6 \\
\hline & 2002-2009 & & & $1921-2015$ \\
\hline
\end{tabular}

1 This study, 2 Hansen et al. (2004) which also report the sampling by Wilce (1964), 3 National Snow and Ice Data Center (Cavalieri and Comiso 2004), 4 Carpenter 2013, 5 http://www.yr.no/place/Norway/Nordland/Flakstad/Lofoten/climate.html\#year, 6 http://www.yr.no/place/Norway/ Troms/Troms\%C3\%B8/Troms\%C3\%B8_observation_site/climate.month01.html

(Hansen 2004). Specimens collected by R.T. Wilce and L. Hansen provided growth estimates for the 2 years prior collection (i.e., years 1957, 1958, 1984, 1985 and 1997, 1998).

\section{Growth rates}

Between 6 and 20 of the oldest thalli of A. nodosum, overall representing 3-17 years of growth, were harvested from all study sites except Kapisillit. On each of the collected specimens we measured the length between consecutive bladders from the tip to the base of the thallus $\left(S_{0}\right.$ : tip to base of 1 st bladder, $S_{1}$ : base of 1 st bladder to base of 2nd bladder, $S_{2}$ : base of 2 nd bladder to base of 3rd bladder, etc. continuing to the holdfast; Fig. 1b). These measurements retrospectively provided estimates of annual growth (assessed as tip elongation rate) of each year along the thallus lifespan. At Kapisillit, we measured the length of the youngest 3 internodes of 20-25 thalli of randomly collected individuals in the mid-intertidal.
Annual growth of $A$. nodosum was retrospectively estimated as the length of a fully grown internode, assuming that it represents 1 year of growth (MacFarlane 1933). This technique was applied to assess the growth during the year previous to collection based on the length of the youngest complete internode $\left(S_{1}\right.$, Fig. 1b), the growth 2 years before collection based on the length of the second youngest complete internode $\left(S_{2}\right.$, Fig. 1b) and so forth for the full length of the thallus. Because the youngest section of the tip $\left(S_{0}\right)$ did not fully grow at the time of sampling, we only included growth estimates of $S_{1}$ and older segments in the analysis.

The assumption that $A$. nodosum tips produce one bladder per year was tested by marking tips at Qeqertarsuaq and Kobbefjord Mid populations. A thin cable tie was placed between the youngest and the second youngest bladder of selected thalli. One year later, the cable tie was displaced to the position between the second and third youngest bladder (Fig. 1b), hence confirming the notion that A. nodosum tips produce one bladder per year. The 
technique was further validated based on reconstructed growth estimates at Kobbefjord populations in August/ September during two consecutive years (2009 and 2010). The length of the segment $S_{1}$ sampled in 2009 hence matched the length of the segment $S_{2}$ measured on thalli collected in 2010.

We estimated the average time series of $A$. nodosum growth for each location by calculating the mean (and standard error) of our growth measurements for each year. For some populations, we could extend the time series back in time using estimates from earlier studies at the same sites. The starting and ending year of the time series of $A$. nodosum annual growth at each location is provided in Table 1 .

The dataset of $A$. nodosum annual growth was expanded with our own measurements of tip growth for 2011 at Kapisillit and annual growth estimates reported in the literature for temperate Atlantic populations. This expanded dataset was used to assess broad-scale latitudinal patterns of $A$. nodosum growth rate across the entire geographical distribution range of the species.

\section{Data on ice-free days and temperature}

The length of the annual sea ice-free period was estimated from satellite images as described by Krause-Jensen et al. (2012) for Qeqertarsuaq, Sisimiut and Nuuk for the period 1990-2009 (Table 1). The satellite images did not allow analysis for Kapisillit, where most pixels contained overlapping land and sea information. The Norwegian sampling sites were not ice-covered. The information was obtained on the basis of sea ice concentration data obtained from passive microwave imagery processed with the Enhanced NASA Team algorithm (Markus and Cavalieri 2000), archived and distributed by the National Snow and Ice Data Center (Cavalieri and Comiso 2004). The length of the icefree period was calculated with an algorithm described by Rodrigues (2009).

Air temperature for the Greenland sites was obtained from the Danish Meteorological Institute (DMI) (Carpenter 2013). We used DMI stations in Nuuk, Sisimiut and Aasiaat and Norwegian Meteorological Institute (MET) in Lofoten and Troms $\varnothing$ for coupling air temperature with $A$. nodosum data (see Table 1). DMI stations provided air temperature time series recorded every $3 \mathrm{~h}$. Annual mean air temperature was calculated by averaging all measurements within each year. MET provided time series of monthly average air temperature values for the Troms $\varnothing$ station. Monthly means of air temperatures at Troms $\varnothing$ were averaged from January to December to calculate the annual mean air temperature for this station. We excluded from the time series the years without records from January to December. We used the annual mean air temperature at Lofoten station provided by MET.

\section{Statistical analysis}

We used linear regression analysis to assess linear temporal trends in climatic variables (ice-free days, air temperature) and in A. nodosum growth. The regression analyses were performed on smoothed time series by a running average of 3 years. Trends in climatic variables were computed for the entire time series and for the period between 1990 and 2012, to encompass the period of $A$. nodosum growth records. Regression analysis was also used to examine the relationships between $A$. nodosum growth and climatic variables. Because the relationship between $A$. nodosum growth and ice-free days across all sites was exponential, we performed the regression analysis on ln-transformed growth estimates. The relationship between A. nodosum growth and latitude across the distribution range of the species was assessed with a quadratic function.

The effect of latitude $(L)$ on temporal linear trends of climatic variables (mean annual air temperature or annual ice-free days) or growth variables $(C)$ was tested using the model:

$C=a_{1}+b_{1} \cdot t+a_{2} \cdot L+b_{2}(t \cdot L)$,

where $a_{1}$ is the intercept of the regression line of variable $C$ with time $(t)$ and $b_{1}$ is the slope of this regression, $a_{2}$ is the change in intercept when $L$ is considered in the model and $b_{2}$ represents the change in the slope $b_{1}$ with changing L. JMP 10.0.0 software was used in all analyses. Statistical significance was set to $p<0.05$.

\section{RESULTS}

Annual mean air temperature at the studied sites since the onset of available records (Table 1) ranged between -8.9 and $4.8^{\circ} \mathrm{C}$ (Fig. 2). Annual mean air temperature at each location exhibited substantial fluctuations, with the temporal pattern differing between the Norwegian and the Greenland coasts (Fig. 2). Annual mean air temperature at Lofoten, since 1900, and at Aasiaat and Sisimiut, since 1950, has significantly increased (Table 2). Warming rates ranged from $0.01 \pm 0.002{ }^{\circ} \mathrm{C}$ per year (Lofoten) to $0.04 \pm 0.01{ }^{\circ} \mathrm{C}$ per year (Sisimiut). Annual mean temperature after 1990 at all observatories, on average, has been between $0.23{ }^{\circ} \mathrm{C}$ (Nuuk) and $1.08{ }^{\circ} \mathrm{C}$ (Sisimiut) higher than before 1990 (Fig. 2). Since 1990, the period when most of Ascophyllum nodosum growth estimates are available, annual mean air temperature showed a significant monotonous increase through time in the Greenland arctic and sub-arctic sites (Table 2). At the Greenlandic sites, air warming showed a steeper increase over the last 3 decades. Significant warming rates of $0.13 \pm 0.02{ }^{\circ} \mathrm{C}$ per year, at Nuuk, and more than $0.2^{\circ} \mathrm{C}$ per year at Aasiaat and 


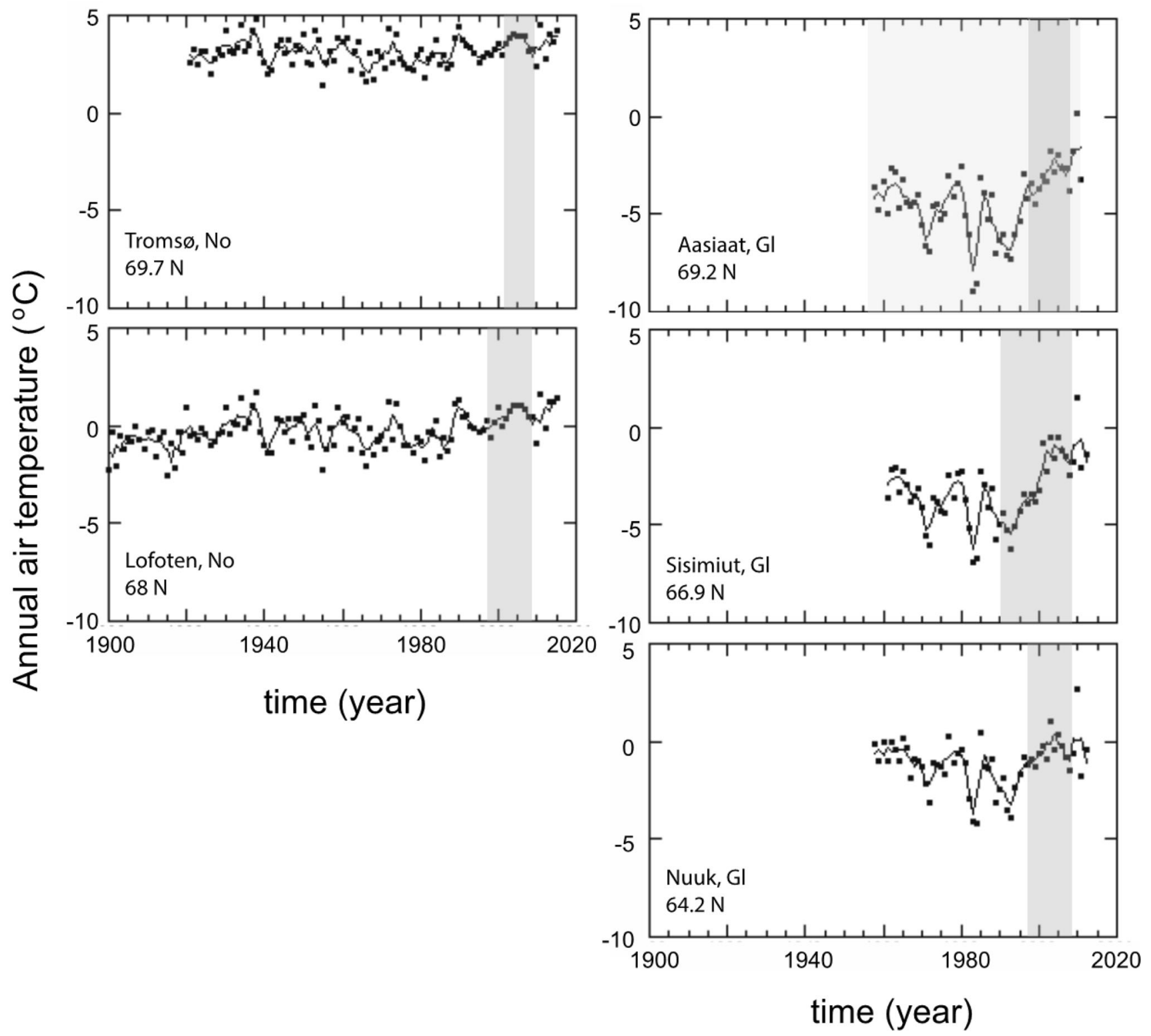

Fig. 2 Time series of annual air temperature recorded at meteorological stations close to each study site. The dots and the solid lines show temperature observations and running mean of 3 year, respectively. Sources of data: http://www.dmi.dk/laer-om/generelt/dmi-publikationer/ 2013/ for Greenland (Gl), http://www.yr.no/place/Norway/Troms/Troms\%C3\%B8/Troms\%C3\%B8_observation_site/climate.month01.html for Troms $\varnothing$ and http://www.yr.no/place/Norway/Nordland/Flakstad/Lofoten/climate.html\#year for Lofoten observations. Grey background indicates the time period of available A. nodosum growth data in the area. For Aasiaat, A. nodosum growth was measured at two stations and both time periods of growth measurements are indicated (Qeqertarsuaq: dark grey; Kronprinsens: light grey)

Sisimiut were recorded (Table S1). Warming rate did not vary across latitude (Table S2).

Troms $\varnothing$ and Lofoten sites were free of sea ice for the entire year because the Gulf Current brings heat along the Norwegian coast. In contrast, all Greenland sites have been covered with sea ice some days of the year since 1990 (Fig. 3). The shortest annual sea ice-free period was recorded at Qeqertarsuaq and Kronprinsens Ejland (52 days). The longest annual sea ice-free period was observed at Kobbefjord sites, even though the fjord was devoid of sea ice during the period 2003-2006. Annual sea ice-free days increased at all Greenland sites since 1990 at rates varying from $2.56 \pm 0.71$ days per year (Kobbefjord, Nuuk) to 9.12 days per year (Qeqertarsuaq and Kronprinsens Ejland, Table 2). The rate of increase of annual sea ice-free days increased with increasing latitude (Table S2).

All A. nodosum populations exhibited inter-annual variability of growth during the studied period. A. nodosum growth tended to increase towards recent time in most of the studied populations (Fig. 4). The growth rate of the tips of $A$. 
Table 2 Regression equations of significant $(p<0.05)$ temporal trends, for the entire time series and for the period since 1990 of annual mean air temperature, annual ice-free days and Ascophyllum nodosum annual tip elongation rate at the study sites. The equations are of the form $Y=a+(b \cdot X)$. The $p$ value and the coefficient of determination are provided. The time periods of the series analysed are indicated. See Table S1 for regression equations with $p$ value $>0.05$

\begin{tabular}{|c|c|c|c|c|c|c|c|c|c|}
\hline$Y$ & $X$ & Site & $\mathrm{b}$ & $\mathrm{SE}_{\mathrm{b}}$ & $\mathrm{a}$ & $\mathrm{SE}_{\mathrm{a}}$ & $p$ value & $R^{2}$ & $\overline{\text { Time period }}$ \\
\hline \multirow{6}{*}{$\begin{array}{l}\text { Mean annual air } \\
\text { temperature }\left({ }^{\circ} \mathrm{C}\right)\end{array}$} & \multirow[t]{6}{*}{ Time (year) } & Lofoten & 0.01 & 0.00 & -20.44 & 3.21 & $<0.0001$ & 0.26 & 1900-2015 \\
\hline & & Aasiaat & 0.03 & 0.01 & -63.98 & 24.15 & 0.02 & 0.10 & $1953-2012$ \\
\hline & & Aasiaat & 0.25 & 0.02 & -505.86 & 42.63 & $<0.0001$ & 0.87 & 1990-2012 \\
\hline & & Sisimiut & 0.04 & 0.01 & -84.12 & 24.02 & 0.00 & 0.18 & 1961-2012 \\
\hline & & Sisimiut & 0.23 & 0.02 & -462.28 & 44.03 & $<0.0001$ & 0.84 & 1990-2012 \\
\hline & & Nuuk & 0.13 & 0.02 & -256.08 & 42.40 & $<0.0001$ & 0.63 & 1990-2012 \\
\hline \multirow{3}{*}{$\begin{array}{l}\text { Annual ice-free days } \\
\quad\left(\text { days } \text { year }^{-1}\right)\end{array}$} & \multirow[t]{3}{*}{ Time (year) } & Qeqertarsuaq & 9.12 & 1.54 & -18055.37 & 3083.33 & $<0.0001$ & 0.66 & 1990-2009 \\
\hline & & Sisimiut & 8.15 & 0.90 & -16023.95 & 1791.25 & $<0.0001$ & 0.82 & 1990-2009 \\
\hline & & Nuuk & 2.56 & 0.71 & -4773.49 & 1422.16 & 0.00 & 0.42 & 1990-2009 \\
\hline \multirow{4}{*}{$\begin{array}{l}\text { Annual tip elongation } \\
\left(\mathrm{cm}_{\text {year }}{ }^{-1}\right)\end{array}$} & \multirow[t]{4}{*}{ Time (year) } & Lofoten & 0.24 & 0.03 & -482.06 & 54.26 & $<0.0001$ & 0.88 & 1997-2009 \\
\hline & & Kronprinsens & 0.09 & 0.02 & -169.95 & 31.06 & $<0.0001$ & 0.67 & 1995-2011 \\
\hline & & Kronprinsens & 0.03 & 0.01 & -54.78 & 11.82 & 0.00 & 0.56 & 1958-2011 \\
\hline & & Kobbe Mid & 0.17 & 0.06 & -343.55 & 119.77 & 0.01 & 0.44 & 1997-2009 \\
\hline \multirow{5}{*}{$\begin{array}{l}\text { Annual tip elongation } \\
\left(\mathrm{cm} \text { year }^{-1}\right)\end{array}$} & \multirow{5}{*}{$\begin{array}{l}\text { Mean annual air } \\
\text { temperature }\left({ }^{\circ} \mathrm{C}\right)\end{array}$} & Lofoten & 2.02 & 0.50 & 4.12 & 0.30 & 0.00 & 0.60 & 1997-2009 \\
\hline & & Kronprinsens & 0.40 & 0.10 & 4.23 & 0.32 & 0.00 & 0.50 & 1995-2011 \\
\hline & & Kronprinsens & 0.28 & 0.07 & 3.88 & 0.27 & 0.00 & 0.44 & 1958-2011 \\
\hline & & Qeqertarsuaq & 0.44 & 0.18 & 4.28 & 0.55 & 0.04 & 0.41 & 1997-2008 \\
\hline & & Kobbe Inner & -0.55 & 0.23 & 5.21 & 0.15 & 0.04 & 0.34 & 1997-2009 \\
\hline $\begin{array}{l}\text { Annual tip elongation } \\
\left(\mathrm{cm} \text { year }^{-1}\right)\end{array}$ & $\begin{array}{l}\text { Annual ice-free days } \\
\left(\text { days year }^{-1}\right)\end{array}$ & Kobbe Mid & 0.082 & 0.024 & -21.84 & 8.57 & 0.01 & 0.51 & 1997-2009 \\
\hline
\end{tabular}

nodosum thalli in the arctic and sub-arctic populations for the last $1-6$ decades ranged between $2.0 \mathrm{~cm}$ per tip and year (Kronprinsens Ejland) and $9.1 \mathrm{~cm}$ per tip and year (Kobbefjord Mid, Fig. 4). The fastest growth was observed after 2005 in all populations except for those at Sisimiut and Qeqertarsuaq where A. nodosum grew at similar rates during the period for which records are available (1997-2009, Fig. 4). A. nodosum growth exhibited significant temporal increasing trends in some populations. At the Kronprinsens Ejland population, that with the longest growth time series recorded, A. nodosum growth increased by, on average, $0.03 \pm 0.01 \mathrm{~cm}$ every year since 1958 (Table 2). The growth rate of this population accelerated after 1990 (Table 2). A significant temporal trend of increased growth after 1990 was also observed at Lofoten and Kobbefjord Mid populations (Table 2), with the Lofoten population showing the fastest increase in annual growth (Table 2). A. nodosum growth tended to decrease towards the north but without a significant relationship with latitude (Table S2).

Spatial and temporal variability of A. nodosum growth at the northern populations were coupled with annual mean air temperature. Overall annual growth of $A$. nodosum tips in these populations increased $0.47 \pm 0.06 \mathrm{~cm}$ per degree $\mathrm{C}$ (regression analysis, $p<0.001, R^{2}=0.45, N=88$, data not shown) and this rate varied across populations (Table 2 ,
Table S1). The fastest increase of A. nodosum annual growth per degree $\mathrm{C}$ of warming since 1990 was observed at the Lofoten population (Table 2, Table S1) followed by Qeqertarsuaq and Kronprinsens Ejland (Table 2, Table S1). The rate of growth increase per degree $\mathrm{C}$ estimated since 1990 at Kronprinsens Ejland was faster in recent years (after 1990) than for the entire period since 1958 (Table 2). Despite that $A$. nodosum annual growth and temperature were not significantly coupled at Tromsø (Table S1), the growth trajectory showed an increase with increasing air temperature and a decrease when air temperature cooled (Fig. 5a). Conversely, temporal growth changes at Sisimiut and Kobbefjord were uncoupled or negatively correlated to temperature variability (Table 2, Table S1).

Temporal and spatial variability of annual growth of $A$. nodosum correlated with that of annual sea ice-free days. Growth of A. nodosum increased exponentially at a rate of $0.3 \pm 0.03 \%$ per day of sea ice-free cover (regression analysis, $p<0.001, R^{2}=0.53, N=75$, data not shown). Local trajectories of $A$. nodosum growth showed a clear coupling to ice-free days at Kobbefjord Mid (Table 2, Table S1) and at Qeqertarsuaq after 1997 but not at the other Greenland study sites (Fig. 5b).

A. nodosum populations located at the northern edge of the species occurrence grew 2.4 times slower than 


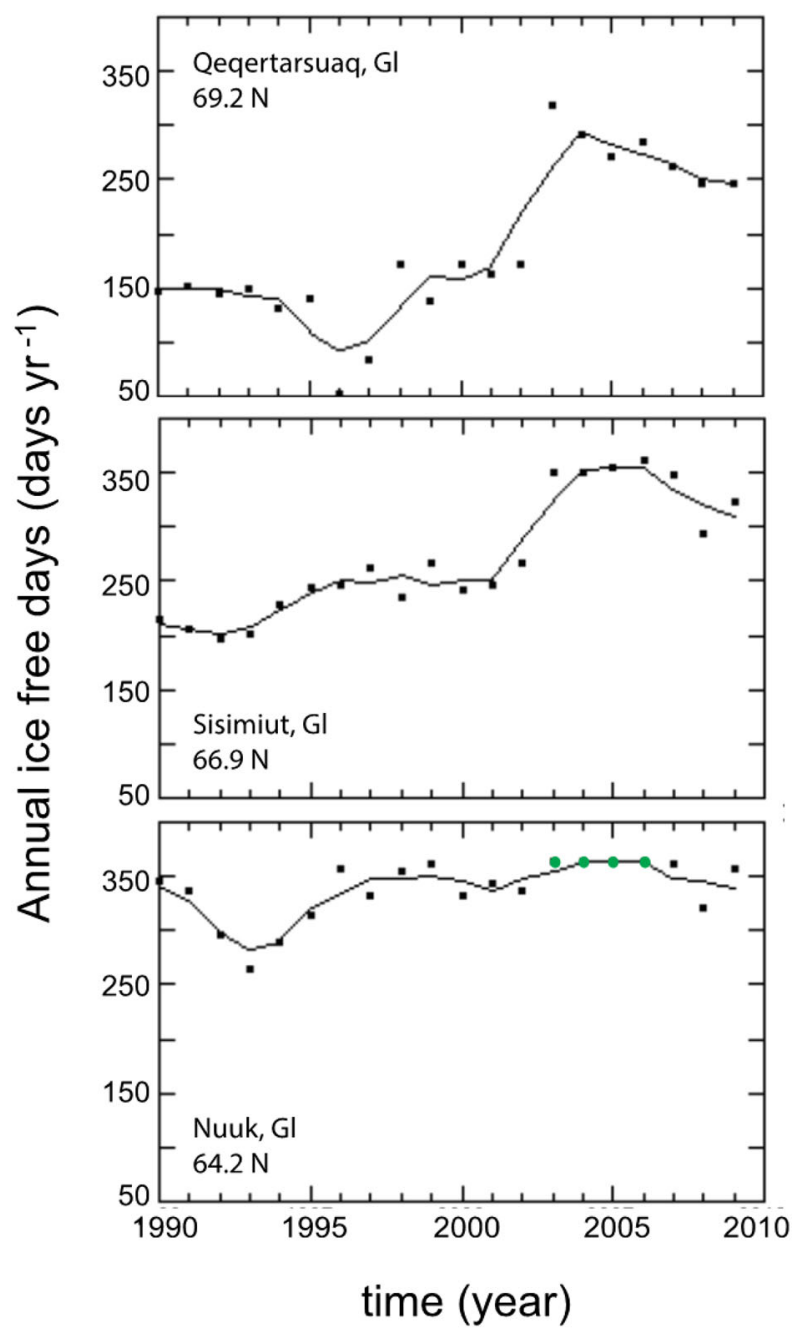

Fig. 3 Time series of annual sea ice-free days at Greenland study sites obtained from satellite images. The dots and the solid lines, respectively, show the annual observations and the running mean of 3 year. Green dots indicate years without sea ice cover

populations located further south, i.e., along the Atlantic coasts (Fig. 6). Indeed, annual growth rate of A. nodosum tended to increase from populations at $40^{\circ} \mathrm{N}$ to those growing at $55^{\circ} \mathrm{N}$, where maximum growth rates were reported (Fig. 6a). Above $60^{\circ} \mathrm{N}$, A. nodosum growth rate rapidly decreased the further north the populations were located (Fig. 6).

\section{DISCUSSION}

This study reports the longest time series on seaweed growth in the sub-arctic region so far published, spanning from one to six decades at the northern edge of Ascophyllum nodosum's distribution range. The longest time series documented significant increases in A. nodosum growth rates over time with the fastest increases occurring since 1990. The temporal trends of faster growth of $A$. nodosum were in agreement with general trends of warming and longer ice-free periods (at sites with seasonal ice cover). All the northern populations above $68^{\circ} \mathrm{N}$ (i.e., Qeqertarsuaq, Kronprinsens Ejland, Lofoten; except Troms $\varnothing$ for which we have only had a short time series) showed a significantly positive temporal increase in annual growth with air warming (Table 2). We also saw a latitudinal trend of increased growth of sub-arctic A. nodosum populations from north to south along Greenland's coast matching the higher temperatures and the reduced sea ice cover towards the south. In addition, our data clearly show that A. nodosum populations grow much faster at $69^{\circ} \mathrm{N}$ along Norway's Gulf Current-influenced coast, than at the same latitude in the colder and partly ice-covered Greenland waters.

Our results show that substantial variability in $A$. nodosum growth at northern populations correlates with temperature $(45 \%)$ and ice-free days (53\%) variability. However, these results also indicate that other environmental factors cause variability in growth. For instance, salinity, which constrains the distribution of macroalgae (Nielsen et al. 1995), varies from 28 to 33\%o in Kobbefjord Mid during the growing season (spring-summer; Sørensen et al. 2015) and may explain the relatively slow growth rates at this site. The growth season of populations located at Lofoten and Troms $\varnothing$ (Norway) is shorter than that at Kobbefjord because of their higher latitudinal location, and this could limit their annual growth rate, despite being exposed to higher temperatures. The degree of wave exposure could also constrain intertidal macroalgal growth since it has been demonstrated that wave exposure increases the stress of rocky shore intertidal communities (Scrosati and Heaven 2007).

Our A. nodosum results are in accord with trends reported for other sub-arctic littoral macroalgal communities in response to arctic warming (Weslawski et al. 2010; Fredriksen and Kile 2012; Fredriksen et al. 2014). Our results also agree with reported trends for sub-arctic subtidal macroalgal communities of increased cover and diversity in Svalbard fjords from 1980 to 2003 (Beuchel et al. 2006) and from 1980 to 2010 (Kortsch et al. 2012), increased macroalgal biomass in other Svalbard fjords over the period 1996-2013 (Bartsch et al. 2016) and increased growth of kelp in response to reduced sea ice cover in North East Greenland over the period 1999-2011 (KrauseJensen et al. 2012). Some of these studies point at intertidal macroalgal communities being more responsive to climate changes than sublittoral communities. Indeed, Helmuth et al. (2006) suggested that intertidal communities are particularly sensitive to changing temperatures.

These results suggest that $A$. nodosum communities are excellent bioindicators of climate change in the marine 


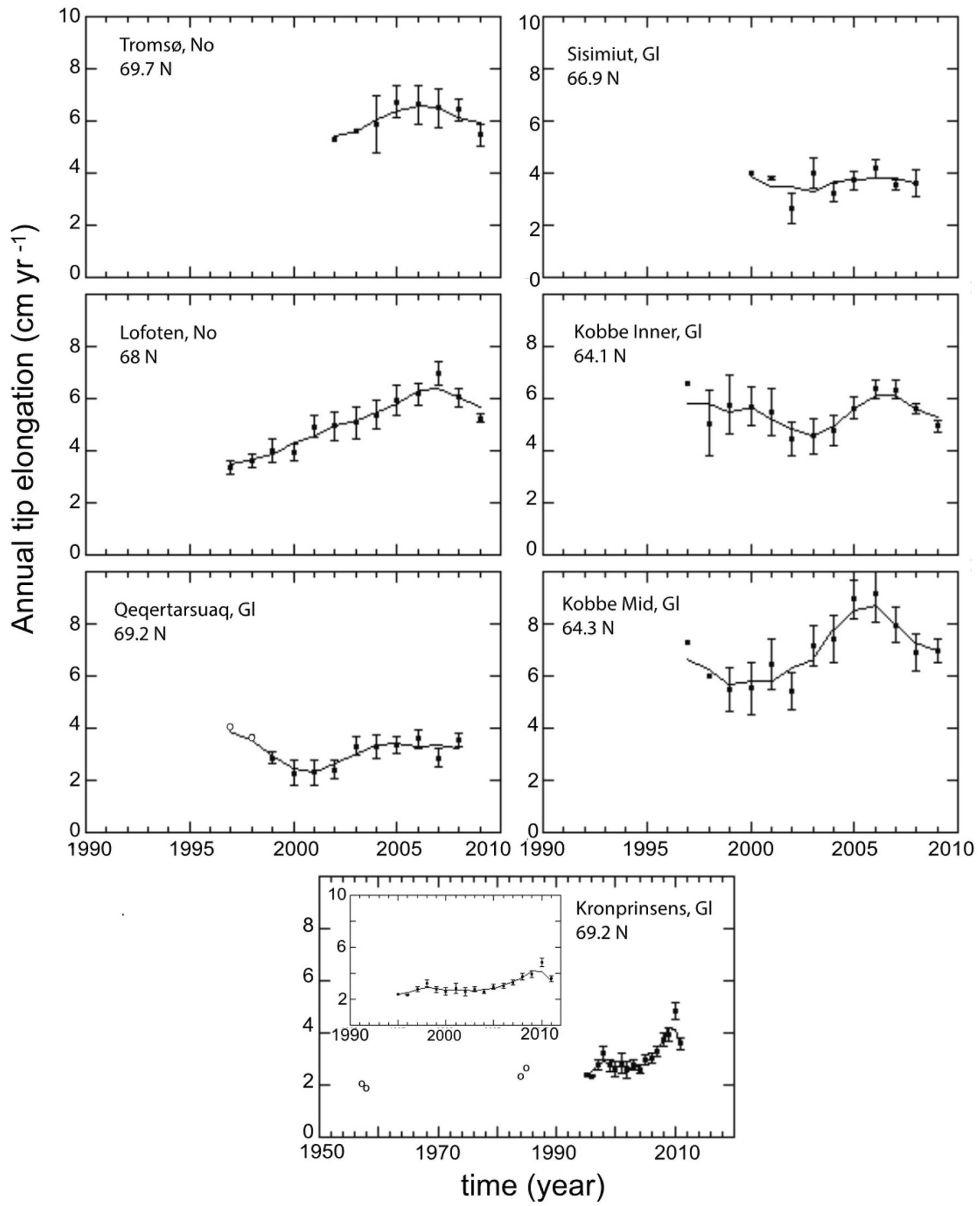

Fig. 4 Time series of Ascophyllum nodosum growth at the studied sub-Arctic and Arctic populations. The dots and the solid lines, respectively, show growth observations and running mean of 3 years. Growth observations at Kronprinsens Ejland in 1957-1958 and 1984-1985 (Wilce 1964; Hansen et al. 2004) and at Qeqertarsuaq in 1997-1998 (Hansen et al. 2004) are identified by open circles. Growth time series at Kronprinsens Ejland since 1995 is highlighted in the inserted plot

arctic, and that the estimation of tip growth of A. nodosum may be used as a relevant parameter in sub-arctic and arctic marine monitoring programmes. In fact, the Greenland Ecosystem Monitoring Programme ${ }^{1}$ has already adopted $A$.

\footnotetext{
${ }^{1}$ www.g-e-m.dk.
}

nodosum tip growth as an important marine bioindicator of environmental change in the Nuuk area, West Greenland.

A. nodosum populations at the northern fringe of subarctic are growing at the slowest rates when compared with those of the species across its the biogeographical 

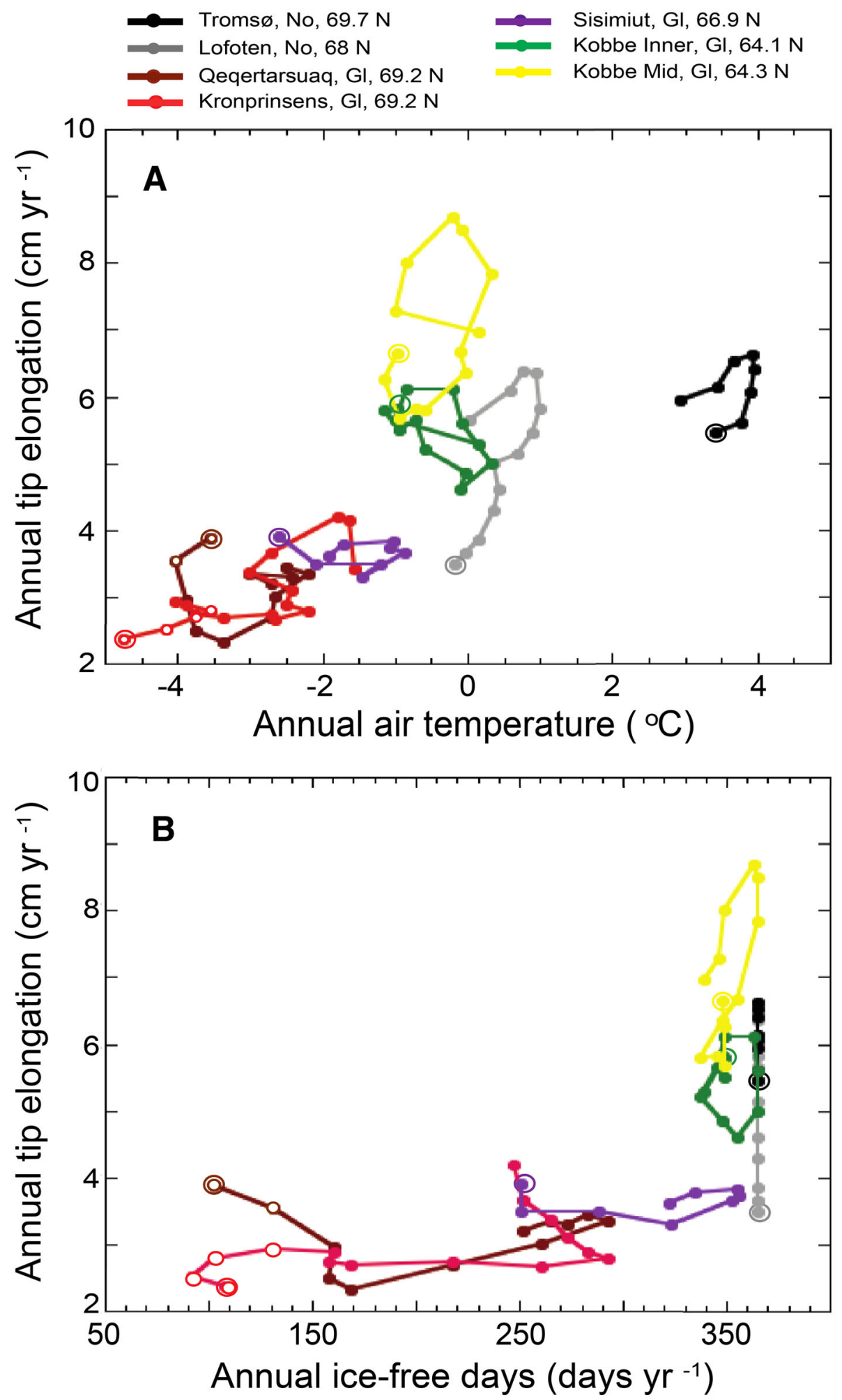

Fig. 5 Trajectories of temporal changes in Ascophyllum nodosum growth with mean air temperature (a) and annual ice-free days (b). Double circles indicate the beginning of the time series. For all variables, the values correspond to the running mean of 3 years. Open circles indicate the growth estimates obtained from Wilce (1964) and Hansen et al. (2004)

distribution range (Fig. 6), which further underlines the stimulating role of temperature. Seawater summer temperature at the northern A. nodosum population ranges from
6 to $14{ }^{\circ} \mathrm{C}$ whereas $A$. nodosum populations below $50^{\circ} \mathrm{N}$, exhibiting maximum growth rates, are exposed to seawater summer temperature exceeding $21^{\circ} \mathrm{C}$ (Keser and Larson 


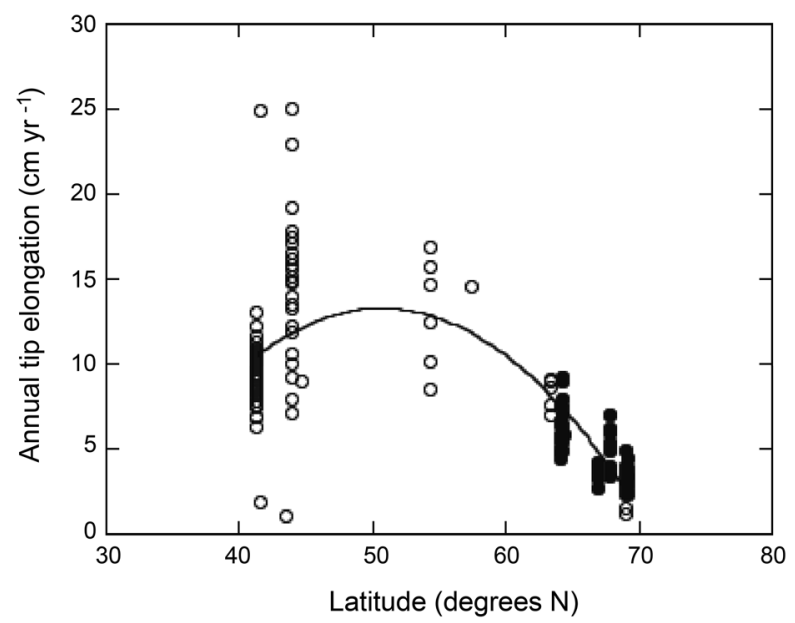

Fig. 6 Ascophyllum nodosum annual tip elongation versus latitude. Filled circles indicate the annual elongation rate of seaweed tips of the studied populations. The solid line indicates the equation fitted $y=30.42$

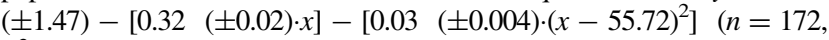
$\left.R^{2}=0.61, p<0.0001\right)$

1984; Peckol et al. 1988; Keser et al. 2005). Independent studies support the positive effect of warming on $A$. nodosum growth until an upper threshold is reached (Fortes and Lüning 1980; Keser et al. 2005; Wilson et al. 2015). An assessment of changes in the abundance of large brown seaweeds across the British Isles over past four decades reports overall favourable effects of warmer summer and winter temperatures on A. nodosum where mean summer temperatures reach a maximum of about $16{ }^{\circ} \mathrm{C}$ (Yesson et al. 2015). Long-term (1979-2002) in situ studies of $A$. nodosum growth in Connecticut, USA, also reported enhanced seaweed growth with warming until temperatures reached $25{ }^{\circ} \mathrm{C}$. Growth rates decreased rapidly and mortality increased as temperatures exceeded $27-28{ }^{\circ} \mathrm{C}$ (Keser et al. 2005). These findings were confirmed experimentally, when warming above $23{ }^{\circ} \mathrm{C}$ resulted in reduced growth and simulations of heat waves $\left(26,29^{\circ} \mathrm{C}\right)$ increased the mortality of A. nodosum in Nova Scotia, Atlantic Canada (Wilson et al. 2015). Both studies are in line with the fact that we found no studies of in situ A. nodosum growth at summer temperatures above $24^{\circ} \mathrm{C}$. Longphuirt et al. (2013) further reported that A. nodosum exhibits higher $\mathrm{CO}_{2}$ affinity at higher temperature, suggesting a seasonal strategy of photosynthetic up-regulation during the growth period. Competitive interactions amongst coexisting intertidal species may also change with warming and affect $A$. nodosum distribution patterns. Indeed, the increased occurrence of Fucus vesiculosus in A. nodosum beds has been attributed to synergetic effect of sea surface warming combined with harvesting (Ugarte et al. 2010).

Recent studies also suggest some poleward migration of A. nodosum in response to warming based on knowledge on temperature tolerance in combination with predicted future isotherm migration (Jueterbock et al. 2013; Neiva et al. 2016). However, these studies do not consider the northernmost Greenland populations neither in the current distribution maps nor in future scenarios. Also the scenarios for Ascophyllum distribution in year 2100 and 2200 suggest retreat of some populations even along the northern distribution limit (Jueterbock et al. 2013; Neiva et al. 2016). Our results suggest that warming of coastal water would lead to an overall stimulation and expansion of the northernmost populations of $A$. nodosum. Future distribution boundaries and the speed of northward migration will, however, also depend heavily on the dispersal capacity of the species.

\section{CONCLUSION}

Our results demonstrate a marked positive response of growth rates of $A$. nodosum populations to warming at the northern fringe of the sub-arctic. A. nodosum as well as the majority of other key species of marine vegetation in Greenland are cold-temperate species with optimum temperatures considerably above current temperature regimes of cold boreal coastal waters (Fortes and Lüning 1980; Müller et al. 2009; Wiencke and Amsler 2012). The stimulating effect of warming on A. nodosum productivity at the northern edge of occurrence may continue well into the future, suggesting more productive intertidal communities in the future sub-arctic. Given the role of A. nodosum as key foundation species, climate change is expected to increase food and habitat provision to intertidal communities.

Acknowledgements This work was funded by projects ATP (EU, FTP7, Grant agreement No. 226248-Arctic Tipping Points) and the Environmental Agency for Mineral Resources Activities (EAMRA) Greenland Government. We thank late Poul M. Pedersen for guiding us to the northernmost populations of Ascophyllum nodosum in Greenland and for measuring marked individuals at Disko Island. We are also grateful to the staff on Hurtigruten's FRAM cruise 2009 for helping us to conduct part of the sampling and to the Greenland Institute of Natural Resources (GINR), Nuuk, Greenland, for providing excellent working conditions and to Flemming Heinrich and Lars Heilmann, GINR, for sailing us in the Godthåbsfjord system. The study is also a contribution to the Greenland Ecosystem Monitoring programme (www.G-E-M.dk) and the Arctic Science Partnership (ASP, asp-net.org).

Open Access This article is distributed under the terms of the Creative Commons Attribution 4.0 International License (http:// creativecommons.org/licenses/by/4.0/), which permits unrestricted use, distribution, and reproduction in any medium, provided you give appropriate credit to the original author(s) and the source, provide a link to the Creative Commons license, and indicate if changes were made. 


\section{REFERENCES}

Åberg, P. 1992. Size-based demography of the seaweed Ascophyllum nodosum in stochastic environments. Ecology 73: 1488-1501.

Araújo, R.M., E.A. Serrao, I. Sousa-Pinto, and P. Aberg. 2014. Spatial and temporal dynamics of Fucoid populations (Ascophyllum nodosum and Fucus serratus): A comparison between central and range edge populations. PLOS ONE 9: e92177.

Bartsch, I., M. Paar, S. Fredriksen, M. Schwanitz, C. Daniel, H. Hop, and C. Wiencke. 2016. Changes in kelp forest biomass and depth distribution in Kongsfjorden, Svalbard, between 1996-1998 and 2012-2014 reflect Arctic warming. Polar Biology. doi:10.1007/ s00300-015-1870-1.

Beuchel, F., B. Gulliksen, and M.L. Carroll. 2006. Long-term patterns of rocky bottom macrobenthic community structure in an Arctic fjord (Kongsfjorden, Svalbard) in relation to climate variability (1980-2003). Journal of Marine Systems 63: 35-48.

Burrows, M.T., D.S. Schoeman, L.B. Buckley, P. Moore, E.S. Poloczanska, K.M. Brander, K.M. Brander, C. Brown, et al. 2011. The pace of shifting climate in marine and terrestrial ecosystems. Science 334: 652-655.

Carpenter, J. 2013. Weather observations Greenland 1958-2012observation data and description. Danish Meteorological Institute. Technical report 13-11. Copenhagen. http://www.dmi.dk/ laer-om/generelt/dmi-publikationer/2013/.

Cavalieri, D., and J. Comiso. 2004. AMSR-E/Aqua daily L3 $12.5 \mathrm{~km} \mathrm{~Tb}$, Sea ice concentrations and snow depth polar grids. National Snow and Ice Data Center, Boulder, CO. Digital Media (updated daily).

Christensen, J.H., K. Krishna Kumar, E. Aldrian, S.-I. An, I.F.A. Cavalcanti, M. de Castro, W. Dong, P. Goswami, et al. 2013. Climate phenomena and their relevance for future regional climate change. In Climate change 2013: The physical sci-ence basis. Contribution of working group I to the fifth assessment report of the intergovernmental panel on climate change, eds. T.F. Stocker, D. Qin, G.-K. Plattner, M. Tignor, S.K. Allen, J. Boschung, A. Nauels, Y. Xia, et al., Cambridge: Cambridge University Press.

Fortes, M.D., and K. Lüning. 1980. Growth rates of North Sea macroalgae in relation to temperature, irradiance and photoperiod. Helgoländer Meeresunters 34: 15-29.

Fredriksen, S., I. Bartsch, and C. Wiencke. 2014. New additions to the benthic marine flora of Kongsfjorden, western Svalbard, and comparison between 1996/1998 and 2012/2013. Botanica Marina 57: 203-216.

Fredriksen, S., and M.R. Kile. 2012. The algal vegetation in the outer part of Isfjorden, Spitsbergen: A revisit of Per Svendsens sites after 50 years. Polar Research 31: 17538. doi:10.3402/polar. v31i0.17538.

Hansen, L. 2004. Buletang Ascophyllum nodosum sammenlignende populationsstudier I grønlandske og danske farvande med særligt henblick på udbredelse, vækst og formering. Master thesis, University of Copenhagen.

Helmuth, B., N. Mieszkowska, P. Moore, and S.J. Hawkins. 2006. Living on the edge of two changing worlds: forecasting the responses of rocky intertidal ecosystems to climate change. Annual Review of Ecology Evolution and Systematics 37: 373-404.

IPCC. 2014. Climate Change 2014: Synthesis report. Contribution of working groups I, II and III to the fifth assessment report of the intergovernmental panel on climate change, eds. R.K. Pachauri, and L.A. Meyer. Geneva: IPCC.

Jueterbock, A., L. Tyberghein, H. Verbruggen, J.A. Coyer, J.L. Olsen, and G. Hoarau. 2013. Climate change impact on seaweed meadow distribution in the North Atlantic rocky intertidal. Ecology and Evolution 3: 1356-1373.
Keser, M., and B.R. Larson. 1984. Colonization and growth of Ascophyllum nodosum (Phaeophyta) in Maine. Journal of Phycology 20: 83-87.

Keser, M., J.T. Swenarton, and J.F. Foertch. 2005. Effects of thermal input and climate change on growth of Ascophyllum nodosum (Fucales, Phaeophyceae) in eastern Long Island Sound (USA). Journal of Sea Research 54: 211-220.

Kortsch, S., R. Primicerio, F. Beuchel, P.E. Renaud, J. Rodrigues, O.J. Lønne, and B. Gulliksen. 2012. Climate-driven regime shifts in Arctic marine benthos. Proceedings of the National Academy of Sciences United States of America 109: 14052-14057.

Krause-Jensen, D., and C.M. Duarte. 2014. Expansion of vegetated coastal ecosystems in the future Arctic. Frontiers in Marine Science 1: 77. doi:10.3389/fmars.2014.00077.

Krause-Jensen, D., N. Marbà, B. Olesen, M.K. Sejr, P.B. Christensen, J. Rodrigues, P.E. Renaud, T.J.S. Balsby, et al. 2012. Seasonal sea ice cover as principal driver of spatial and temporal variation in depth extension and annual production of kelp in Greenland. Global Change Biology 18: 2981-2994. doi:10.1111/j.13652486.2012.02765.x.

Longphuirt, S.N., C. Eschmann, C. Russell, and D.B. Stengel. 2013. Seasonal and species-specific response of five brown macroalgae to high atmospheric $\mathrm{CO}_{2}$. Marine Ecology Progress Series 493: 91-102.

Lüning, K. 1990. Seaweeds: their environment, biogeography, and ecophysiology. New York: Wiley.

MacFarlane, C. 1933. Observations on the annual growth of Ascophyllum nodosum. Proceedings of the Nova Scotian Institute of Science 18: 1930-1934.

Markus, T., and D. Cavalieri. 2000. An enhancement of the NASA Team sea ice algorithm. IEEE Transactions on Geoscience and Remote Sensing 38: 1387-1398.

Merzouk, A., and L.E. Johnson. 2011. Kelp distribution in the northwest Atlantic Ocean under a changing climate. Journal of Experimental Marine Biology and Ecology 400: 90-98.

Müller, R., T. Laepple, I. Bartsch, and C. Wiencke. 2009. Impact of oceanic warming on the distribution of seaweeds in polar and cold-temperate waters. Botanica Marina 52: 617-638.

Neiva, J., E.A. Serrão, J. Assis, G.A. Pearson, J.A. Coyer, J.L. Olsen, G. Hoarau, and M. Valero. 2016. Climate oscillations, range shifts and phylogeographic patterns of North Atlantic Fucaceae. In Seaweed phylogeography: Adaptation and evolution of seaweeds under environmental change, ed. Z.M. Hu, and C. Fraser, 279-308. Dordrecht: Springer. doi:10.1007/978-94-017-7534-2.

Nielsen, R., A.A. Kristiansen, L. Mathiesen, and H. Mathiesen. 1995. Distributional index of the benthic macroalgae of the Baltic Sea área. Acta Botanica Fennica 155: 1-51.

Olesen, B., D. Krause-Jensen, N. Marbà, and P.B. Christensen. 2015. Eelgrass (Zostera marina L) in subarctic Greenland: Dense meadows with slow biomass turnover in cold waters. Marine Ecology Progress Series 518: 107-121. doi:10.3354/meps11087.

Peckol, P., M.M. Harlin, and P. Krumscheid. 1988. Physiological and population ecology of intertidal and subtidal Ascophyllum nodosum (Phaeophyta). Journal of Phycology 24: 192-198.

Pedersen, P.M. 2011. Grønlands Havalger. Frederiksberg: ForlagetEpsilon.

Poloczanska, E.S., C.J. Brown, W.J. Sydeman, W. Kiessling, D.S. Schoeman, P.J. Moore, K. Brander, J.F. Bruno, et al. 2013. Global imprint of climate change on marine life. Nature Climate Change 3: 919-925.

Rodrigues, J. 2009. The increase of the length of the ice-free season in the Arctic. Cold Regions Science and Technology 59: 78-101. doi:10.1016/j.coldregions.2009.05.006.

Schmidt, A.L., M. Coll, T.N. Romanuk, and H.K. Lotze. 2011. Ecosystem structure and services in eelgrass Zostera marina and rockweed Ascophyllum nodosum habitats. Marine Ecology Progress Series 437: 51-68. 
Scrosati, R., and C. Heaven. 2007. Spatial trends in community richness, diversity, and evenness across rocky intertidal environmental stress gradients in eastern Canada. Marine Ecology Progress Series 342: 1-14.

Sejr, M.K., M.E. Blicher, and S. Rysgaard. 2009. Sea ice cover affects inter-annual and geographic variation in growth of the Arctic cockle Clinocardium ciliatum (Bivalvia) in Greenland. Marine Ecology Progress Series 389: 149-158.

South, G.R., and I.Tittley. 1986. A checklist and distributional index of benthic marine algae of the North Atlantic Ocean. Huntsman Marine Laboratory, St Andrews, New Brunswick and The British Museum of Natural History, London.

Sørensen, H.L., L. Meire, T. Juul-Pedersen, H.C. de Stigter, F.J.R. Meysman, S. Rysgaard, B. Thamdrup, and R.N. Glud. 2015. Seasonal carbon cycling in a Greenlandic fjord: an integrated pelagic and benthic study. Marine Ecology Progress Series 539: $1-17$.

Steneck, R.S., M.H. Graham, B.J. Bourq, D. Corbett, and J.M. Erlandson. 2002. Kelp forest ecosystems, biodiversity, stability resilience and future. Environmental Conservation 29: 436-459. doi: $10.1017 /$ S0376892902000322.

Stengel, D.B., and M.J. Dring. 1997. Morphology and in situ growth rates of plants of Ascophyllum nodosum (Phaeophyta) from different shore levels and responses of plants to vertical transplantation. European Journal of Phycology 32: 193-202.

Straub, S.C., Thomsen, and T. Wernberg. 2016. The dynamic biogeography of the Anthropocene: The speed of recent range shifts in seaweeds. In Seaweed phylogeography: Adaptation and evolution of seaweeds under environmental change, ed. Z.M. $\mathrm{Hu}$, and C. Fraser, 63-93. Dordrecht: Springer. doi:10.1007/97894-017-7534-2.

Ugarte, R.A., J.S. Craigie, and A.T. Critchley. 2010. Fucoid flora of the rocky intertidal of the Canadian maritimes: Implications for the future with rapid climate change. In Seaweeds and their role in globally changing environments, ed. J. Seckbach, R. Einav, and A. Israel, 69-90. Dordrecht: Springer.

Vaughan, D.G., J.C. Comiso, I. Allison, J. Carrasco, G. Kaser, R. Kwok, P. Mote, T. Murray, et al. 2013. Observations: cryosphere. In Climate change 2013: The physical science basis. Contribution of working group I to the fifth assessment report of the intergovernmental panel on climate change, ed. T.F. Stocker, D. Qin, G.-K. Plattner, M. Tignor, S.K. Allen, J. Boschung, A. Nauels, Y. Xia, et al., 317-382. Cambridge and New York: Cambridge University Press.

Viana, I.G., A. Bode, and C. Fernández. 2014. Growth and production of new recruits and adult individuals of Ascophyllum nodosum in a non-harvested population at its southern limit (Galicia, NW Spain). Marine Biology 161: 2885-2895.

Wassmann, P., C.M. Duarte, S. Agusti, and M.K. Sejr. 2011. Footprints of climate change in the Arctic marine ecosystem. Global Change Biology 17: 1235-1249.

Weslawski, J.M., J. Wiktor, and L. Kotwicki. 2010. Increase in biodiversity in the arctic rocky littoral, Sorkappland, Svalbard, after 20 years of climate warming. Marine Biodiversity 40: $123-130$.

Wiencke, C., and C.D. Amsler. 2012. Seaweeds and their communities in polar regions. In Seaweed biology, ecological studies 219, ed. C. Wiencke, and K. Bischof, 265-291. Berlin: Springer.

Wilce, R.T. 1964. Studies on benthic marine algae in north-west Greenland. In Proceedings of the international seaweed symposium, ed. A. Day de Virville, and J. Feldmann, 280-286.

Wilce, R.T. 2016. The "Arctic stamp" its imprint on an endangered marine flora. Perspectives in Phycology. In press.

Wilson, K.L., L.M. Kay, A.L. Schmidt, and H.K. Lotze. 2015. Effects of increasing water temperatures on survival and growth of ecologically and economically important seaweeds in Atlantic Canada: Implications for climate change. Marine Biology 162: 2431-2444.

Yesson, C., L.E. Bush, A.J. Davies, C.A. Maggs, and J. Brodie. 2015. Large brown seaweeds of the British Isles: Evidence of changes in abundance over four decades. Estuarine, Coastal and Shelf Science 155: 167-175.

Zacher, K., R. Rautenberger, D. Hanelt, A. Wulff, and C. Wiencke. 2009. The abiotic environment of polar marine benthic algae. Botanica Marina 52: 483-490.

\section{AUTHOR BIOGRAPHIES}

Núria Marbà $(\bowtie)$ is a Research Investigator at the Institut Mediterrani d'Estudis Avançats. Her research interests include marine ecology and global change.

Address: Department of Global Change Research, IMEDEA (CSICUIB), Miquel Marquès 21, 07190 Esporles (Illes Balears), Spain. e-mail:nmarba@imedea.uib-csic.es

Dorte Krause-Jensen is a Senior Scientist at the Aarhus University. Her research interests include the ecology of marine macrophytes. Address: Department of Bioscience, Aarhus University, Vejlsøvej 25, 8600 Silkeborg, Denmark.

Address: Arctic Research Centre, Aarhus University, Ny Munkegade 114, Building 1540, 8000 Århus C, Denmark.

e-mail: dkj@bios.au.dk

Birgit Olesen is an Associate Professor at the Aarhus University. Her research interests include ecophysiology of macrophytes.

Address: Department of Bioscience, Aarhus University, Ole Worms Allé 1, Building 1135, 8000 Aarhus C, Denmark.

e-mail: birgit.olesen@bios.au.dk

Peter B. Christensen is a Senior Scientist at the Aarhus University. His research interests include marine ecology.

Address: Arctic Research Centre, Aarhus University, Ny Munkegade 114, Building 1540, 8000 Århus C, Denmark.

e-mail: pbc@bios.au.dk

Anissa Merzouk is a Project Coordinator at the Universite Laval. Her research interests include seaweed ecology.

Address: ArcticNet/Amundsen Science, Université Laval, Pavillon Alexandre-Vachon, Room 4081, 1045 Avenue de la Médecine, Quebec, QC G1V 0A6, Canada.

e-mail: Anissa.Merzouk@arcticnet.ulaval.ca

Joao Rodrigues is a Research Associate at the University of Cambridge. His research interests include arctic sea ice production and climate change.

Address: St Catharine's College, University of Cambridge, Cambridge CB2 1RL, UK.

e-mail: jmr64@cam.ac.uk

Susse Wegeberg is a Senior Advisor at the Aarhus University. Her research interests include arctic ecology.

Address: Department of Bioscience, Aarhus University, Frederiksborgvej 399, 4000 Roskilde, Denmark.

e-mail: suwe@dmu.dk

Robert T. Wilce is a Professor at the University of Massachusetts. His research interests include seaweed ecology in the Arctic Ocean. Address: Department of Biology, University of Massachusetts, Amherst, MA 01003, USA.

e-mail: rwilce@bio.umass.edu 